\title{
Diagnostic pitfalls of varicella virus infection in adults
}

\author{
Alina Demetrian ${ }^{1 *}$, Gabriela lliescu $^{2}$ \\ From The 9th Edition of the Scientific Days of the National Institute for Infectious Diseases Prof Dr Matei Bals \\ Bucharest, Romania. 23-25 October 2013
}

\section{Background}

Usually, varicella in adults has a more severe evolution than in children, with a higher incidence of complications.

\section{Case report}

We present three cases of previously healthy adult patients diagnosed with varicella in December 2012 with uncommon onsets, but with mild evolution of the disease.

Patient 1: female, age 45, had an atypical onset with very few vesicles - only one on the trunk, and then on the head after five days, but with inflammatory occipital lymph nodes. From day 6, our patient had typical dermatological lesions, mild pruritus and only two days of mild fever.

Patient 2: male, age 38, had a typical onset, with high fever in the first week. With another episode of varicella in his childhood, this was considered as a varicella virus recurrent infection.

Patient 3: male, age 80, was admitted to the hospital for extremely painful cutaneous eruptions on the thorax, initially diagnosed as zona zoster. In the next days, the lesions, in different stages of development, extended all over the body, with typical evolution of chickenpox.

All patients were treated with supportive therapy: antipruritic and anti-inflammatory drug mouthwashes, soothing topical lotions and anesthetic gels. They had self-limited evolution, with no complications and with complete remission of lesions.

\section{Conclusion}

The incidence of chickenpox in adults seems to be higher in last years. As varicella-zoster virus infection can present unusual manifestations, clinicians must be

\footnotetext{
* Correspondence: asdemetrian@yahoo.com

${ }^{1}$ Emergency County Hospital Târgu Jiu, Romania

Full list of author information is available at the end of the article
}

aware of these presentations and be prepared to perform appropriate diagnostic and treatment.

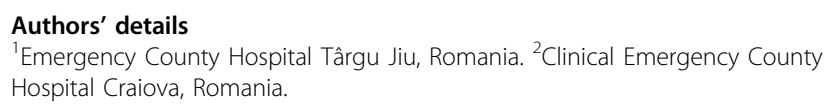

Published: 16 December 2013

doi:10.1186/1471-2334-13-S1-P70

Cite this article as: Demetrian and lliescu: Diagnostic pitfalls of varicella virus infection in adults. BMC Infectious Diseases 2013 13(Suppl 1):P70.
Submit your next manuscript to BioMed Central and take full advantage of:

- Convenient online submission

- Thorough peer review

- No space constraints or color figure charges

- Immediate publication on acceptance

- Inclusion in PubMed, CAS, Scopus and Google Scholar

- Research which is freely available for redistribution

Submit your manuscript at www.biomedcentral.com/submit

\section{() Biomed Central}

\section{Ciomed Central}

